\title{
Pecze Máté
}

\section{Két régió klaszteralapítási kezdeményezéseinek összehasonlítása a 2008-as regionális klaszterpályázatokon keresztül}

\begin{abstract}
A magyar kormányzat elindította kezdeményezését a vállalkozói együttmüködések új, klasztereken keresztüli támogatására, bár még nem biztos, hogy a gazdaság és a helyi szerelök felkészültek lennének erre a módszerre. Csakúgy, mint más régiókban, Észak-Magyarországon és az Észak-Alföldön is új klaszterek indultak, hogy elnyerjék a támogatást. Az együttmüködésük minősége, a benyújtott pályázatok száma, valamint a nyertes projektek köre/aránya megmutatja, hogy a klaszterelmélet és a nyugati gyakorlat alkalmazása az itthoni környezetben mit eredményez, a magyar vállalatok tudnak-e, akarnak-e klaszterekben dolgoni. Ezen cikkben a régiók gazdasági szereplőinek a hajlandóságát/aktivitását vizsgálom a 2008-as régiós klaszterkiírásokban. Észak-Magyarország és Észak-Alföld hasonló, de nem teljesen egyező eredménnyel rendelkezik.
\end{abstract}

Journal of Economic Literature (JEL) kód: R58, L2

Kulcsszavak: klaszterek, finanszírozás, regionális pályázatok, vállalkozói aktivitás, benyútott projektek

Az európai trenddel összhangban, ám kicsit késve, Magyarországon is megjelent egy új gadságfejlesztési irányzat, és meghatározta a kormányzat vállalkozásfejlesztési stratégiáját. Ez a klaszter alapú gazdaságfejlesztés, amit Lengyel (2002) a gazdaságfejlesztési iskolák negyedik lépcsőjeként értelmez ${ }^{1}$. Klaszter alapú fejlesztésben a kormány a vállalkozások együttműködő csoportjait támogatja, amelyek az együttmüködéssel növelni tudják lobbyerejüket, pénzt takarítanak meg, és közösen fejlesztik üzleti lehetőségeiket. A klaszter elsődleges definíciójához Michael E. Portert idézzük: „Az üzleti klaszter egymáshoz kapcsolt vállalkozások, beszállítók és kapcsolódó intézmények földrajzi koncentrációja egy bizonyos ágazatban. Klaszterekkel a vállalkozások növelhetik termelékenységüket, ami által nő a versenyképességük nemzeti és globális szinten. Településtudományban erre az agglomeráció szót használják.” (Porter1998).

Közép-Európában a klaszterek létrejöttének két folyamatát is megfigyelhetjük: vannak természetes klaszterek, amiket a vállalatok saját maguk állítanak fel, mert az együttmüködében üzleti lehetőségeket ismertek fel, ezt ezért nevezhetjük alulról jövő folyamatnak. A szakirodalom ezt a módszert tartja kívánatosnak, szerencsésnek, bár ez csak olyan földrajzi területeken müködik, amik rendelkeznek speciális elöfeltételekkel, 
pl. a kis- és középvállalkozások szükséges számával, kritikus tömegével (e mellett sok más feltételt leír Sölvell et al. 2003). Ahol ezek az ipari kezdeményezések hiányoznak, vagy nem hatékonyak, ott a kormányzat megpróbálja támogatni, felgyorsítani ezeket - csakúgy, mint Magyaroszágon. Ezek a felülről jövő kezdeményezések (top-down), melyekkel a klaszterek alakulását igyekeznek elösegíteni, divatos gazdaságfejlesztési eszközzé váltak a volt szocialista országokban is. Közben persze a gazdasági hátterük, adottságaik országonként, de még régiónként is jelentősen eltérnek.

$\mathrm{Az}$ általános üzleti környezet meghatározó jelleggel bír a klaszterek kialakulásában (klaszterizáció). Az üzleti környezetet és a mikrogazdasági politikákat ${ }^{2}$ pedig legfelsőbb sziten a makrogazdasági helyzet és a nagypolitika befolyásolja (Sölvell et al. 2003).

Véleményem szerint az általános üzleti és a mikrogazdasági környezet Magyarországon nem optimális a sikeres klaszterfejlesztésre. A Cluster Policies Whitebook (Andersson et al. 2004) szerint az üzleti klaszterek kialakulásának legszükségesebb feltétele a meglévő erős szociális tőke és a bizalom, akár alulról jövő, akár kormányzati kezdeményezésként indulnak. Magyarországon ezek a tényezők gyengék, és nem is erősíthetőek meg néhány év alatt.

2000 után - más országokkal együtt - Magyarországon is megjelent a klaszterek elmélete és a gyakorlati alkalmazása a regionális politikákban, amelynek első jele a Széchenyi-terv volt. Második lépésként az EU-csatlakozás után Magyarország kidolgozott egy fejlesztési programot az EU-iránymutatásokkal összhangban, ez volt a Nemzeti Fejlesztési Terv (NFT). Ez többek között olyan pályázati kírásokat is tartalmazott, amik pénzügyi segítséget adtak vállalkozásoknak, hogy klasztereket, hálózatokat alakítsanak. Ez a keretprogram 2004 és 2006 között müködött. 2007-től kezdődően ennek utóda, az NFT 2, más néven az ÚFMT (Új Mgyarország Fejlesztési Terv) tartalmazza az aktuális iránymutatásokat a gazdaságfejlesztésre nézve. Anyagilag sokkal nagyobb az előzőnél: elméletileg 8000 milliárd Ft érhető el belőle a 7 éves tervezési időszak alatt 2013-ig.

$\mathrm{Az}$ UMFT-nek létezik regionális és ágazati dimenziója is. Az utóbbira példa a Gazdasáfejlesztési Operatív Program; ebben is vannak kiírások speciálisan klaszterek számára ${ }^{3}$, ahol termékfejlesztésre és exportra érhető el támogatás leginkább. Ezek a kírások már müködő, komoly együttmüködést felmutatni tudó klaszterek számára szólnak, és előfeltétel, hogy a Pólus Program keretében egy akkreditációs minőségellenőrzésen megfeleljen a klaszter ${ }^{4}$.

A regionális rész alatt a Regionális Operatív Programok értendőek. Minden régiónak megvolt a lehetősége, hogy saját igényei, adottságai alapján fejlesztési tervet dolgozzon ki. Bizonyos keretek között ők dönthették el, hogy a rendelkezésre álló forrásokból milyen arányban és milyen területen akarnak pénzeket pályázatok útján elérhetővé tenni. A

\footnotetext{
2 A mikrogazdasági "motor olajozását" szolgáló klasztertámogatási kezdeményezésekkel együtt

3 Itt 2010 tavaszán két pályázat volt kimondottan klasztereknek címezve: GOP-2009-1.2.1. Akkreditált innovácós klaszterek támogatása; GOP-2010-1.3.1/B - Akkreditált klaszterek vállalati innovációjának támogatása.

4 A Pólus Program dolgozta ki Magyarország klaszterfejlesztési politikáját. Négy fejlesztési fázist különített el. Az első kettő a fiatal klasztereknek szól (induló és fejlődő klaszterek), és a regionális programokból nyernek finanszírozást, a harmadik az akkreditált klaszterek szintje, a negyedik pedig egy későbbi, még fejlettebb fázist jelent. Az akkreditáció célja, hogy a támogató kiszürhesse az olyan pályázókat, amelyek együttműködése piacilag nem igazolt, valós együttműködéseket nem mutatnak fel. Az akkreditáció során a közös projekteket, a tagok flyamatos növekedését, üzleti sikereit kell bizonyítaniuk a pályázóknak. A fiatal együttmüködéseket támogató ROP-ok után a Pólus Program az akkreditációval az innovatív és exportképes klaszterek támogatását célozza. „A nem innovatív és exportorientált klaszterek számára viszont a jelenlegi támogatási rendszer nem nyújt semmilyen további pályázati lehetőséget" (Szanyi M. 2008).
} 
régióknak 2008-tól volt pályázati kiírásuk klaszterek támogatására is, ezek a kiírások a GOP-pal elletében a fiatal klasztereket támogatják. A következőkben ezek eredményét vizsgáljuk meg két régióban közelebbről, mert ezen kiírások szólnak az újonnan alakuló együttmüködések, klaszterek támogatásáról, és a későbbi fejlesztéseket ezen projektek sikere alapozhatja meg.

\section{Pályázati felhívások klaszterek számára az Észak-magyarországi és az Észak-alföldi Operatív Programban}

A ROP-kiírásokban elkülönítettek induló és fejlödő klasztereket is ${ }^{5}$ (a Pólus Program 1. és 2. fejlesztési fázisa). A fejlődőknél nagyobb hangsúlyt fektettek a korábbi együttműködés igazlására, valamint támogatandó tevékenységként a menedzsment-költségeken kívül (bér, utazás, tanácsadás stb.) egy konkrét beruházást is meg kellett valósítania a pályázóknak. A pályázatok elemzése során a tanulmány nem tesz különbséget induló és fejlődő klaszterek között, mert a pályázati aktivitás, együttmüködés szempontjából a két kategória egyformán fontos.

Az Észak-magyarországi és az Észak-alföldi Operatív Programban is volt ilyen kiírás, amivel az újonnan születő klasztereket támogatták. Előbbinek kódja: ÉMOP-2008-1.2.1; regionális jelentőségű klaszterek közös beruházásainak támogatása, szolgáltatásainak kialaktása és fejlesztése, az észak-alföldié: ÉAOP-2008-1.1.2; klasztermenedzsmentszervezetek létrehozása, megerősítése. Habár a nevek különbözően hangzanak, a két felhívás gyakorlati célja ugyanaz volt: pénzügyi segítséget nyújtani a fiatal klaszterirodák menedzmentköltségeihez és a tagok közös beruházásaihoz.

A feltételek megengedték, hogy vadonatúj vállalati csoportok is pályázhassanak, ami a következö helyzetet eredményezte: olyan kkv-k is pályáztak, amelyek között elötte nem volt semmiféle közös múlt, együttmüködés. A pályázati kiíráshoz igazítva felépítették gyorsan a klaszterüket, „feltöltötték” a tagságot a megfelelő szervezetekkel, és beadták a pályázatot. Egyrészről ez a források pazarlását jelenti, mert véleményem szerint a pénz nagy része nem a régió gazdaságának fejlesztésében fog hasznosulni: a gyorsan alakult klaszterek (inkább talán projekttársaságok, konzorciumok) egy része a támogatási összeg elnyeréséért alakult, és a biztos talajt nélkülöző kapcsolat a projekt futamideje és a kifizetés után valószínűleg felbolik.

Más felfogásban viszont a kiírás megengedő feltételei egyenlő esélyeket adnak minden új üzleti csoportnak, hogy felállítsanak egy hivatalos keretet az együttmüködéshez, és anyagi támogatás mellett elkezdjenek ismerkedni, együttmüködni. A sok támogatott klaszterből (10-20 darabos nagyságrend régiónként) idővel pedig a nem megfelelő klaszterek felbomlanak, és maradnak a sikeresen müködők.

A következő részben az észak-magyarországi és észak-alföldi vállalkozások klaszteralakítási törekvéseit vizsgálom: összehasonlítom a vállalkozói hajlandóságot arra nézve, hogy milyen aktívak klaszterek alapításában és a fönt említett kiírásokra történő pályázásban. Mivel nem a sikerességet vizsgálom, hanem a hajlandóságot, igényt,

\footnotetext{
5 Induló kategóriában maximum 50 millió, fejlödöben 250 millió Ft-ra lehetett pályázni. A menedzmentköltségeknél 80\%, a közös beruházási költségeknél 50\% volt a támogatási arány. Az induló vagy fejlődő kategóriába a pályázók sorolták magukat, és a kiírásban nem volt komolyabb kontroll ezzel kapcsolatban.
} 
aktivitást, kezdeményezői készséget, ezért nem a nyertes, hanem a beadott projekteket elemzem. A benyújtott projekttervek száma, minősége sokat mond nekünk a két régió cégeinek aktivitásról, a köztük lévő kapcsolat szintjéről, egymás iránti bizalmáról. A beérkezett projektek egy része nem kapott támogatást, elutasították, ám ezen tanulmány szempontjából ugyanolyan értékesek, mint a nyertesek. Ezek a ROP-pályázatok voltak az egyetlen régiós kiírások, amelyen alakuló klaszterekre lehetett támogatást szerezni, ezért a megmutatkozó pályázói hajlandóság vizsgálatával információhoz juthatunk a cégek közötti bizalomról, együttműködési potenciálról, mely tényezőket a korábbiakban az üzleti klaszterek alakításának legfontosabb alapköveként emlegettük és emlegeti a szakirodalom.

\section{A módszer korlátai}

A vizsgálat alatt kompromisszumokat kellett kötnöm. Amikor a projektekben szereplö partnerekről írok, fontos szólni arról, hogy egy-egy vállalkozás tagja lehetett több beadott projektnek/klaszternek is, mert ilyen megkötés nem volt a kiírásokban. Az egyes projektdokumentációkból volt kiolvasható a partnerek száma, így elöfordulhatott, hogy az elemzésben egy vállalkozást többször vettem számításba, mert több klaszterben nyilván volt tartva. Ez viszont a téma szempontjából nem jelent problémát, mert a cégek aktivitását, hajlandóságát mérem, amit a többszörös számolás jól tükröz. Nem lett volna érdemes ezeket a pluszszerepléseket levonni az összesből, így a későbbiekben fontos, hogy amikor a klasztertagok számáról írok, valójában ez inkább a jelentkezések száma. Egy tag többszörös tagsága klaszterekben egyébként ritka. Főiskolák, egyetemek, kutatóintézetek voltak ilyen helyzetben, számuk az összes partnerhez képest pedig elenyésző.

Másodszor, az egyszerűség kedvéért a továbbiakban a vállalkozások kifejezés alatt, az egyéni vállalkozó kivételével, minden vállalkozás alatt klasztertagszervezetet értek.

\section{Klaszteralakítási hajlandóság a két régióban a két regionális klaszterpályázat tekintetében}

A pályázók számának tekintetében a következőket figyelhetjük meg: a KSH adatai szerint 48000 gazdasági szervezet ${ }^{6}$ volt 2008-ban Észak-Magyarországon (ÉM) és 59000 az Észak-Alföldön (ÉA). Ezzel szemben ÉM-on 36, míg az ÉA-ön sokkal kevesebb, csupán 20 pályázat érkezett be, és emellett a projektekben sorolt partnerek ${ }^{7}$ száma is jóval nagyobb: 506, ill. 392. Ezeket figyelembe véve a következő megállapításokat tehetjük:

1) ÉM-on a vállalkozások hajlandósága nagyobb volt, mint az ÉA-ön. Itt 100 cégből 1,05 akart klaszterben partner lenni, míg az alföldi régióban ez csak 0,67.

2) ÉM-on a pályázó klaszterek átlagos nagysága 14,05 partner per klaszter volt, és ugyanez 19,60 az ÉA-ön. Tehát az alföldi régióban a pályázó klaszterek mérete a tagszámot tekintve nagyobb.

${ }^{6}$ Társas vállalkozások a nonprofit szervezetekkel együtt, kivéve az egyéni vállalkozók.

7 Ne felejtsük: egy tag több klaszterben is pályázhatott, így ha pontosak akarunk lenni, a tagok vagy partnerek száma inkább a jelentkezések számát tükrözi. 


\section{Beadott projektek a pályázó szervezet székhelye alapján}

36 projekt érkezett be ÉM-on, és 20 ÉA-ön. Érdekes, hogy előbbi régióban volt egy projekt, aminek a pályázó szervezete a másik (ÉA-i) régióban székel. Ez azt jelenti, hogy egy debreceni cég az észak-magyarországi pályázati kiírásra jelentkezett - az alakítandó klaszter székhelye valószínüleg ÊM-on lett volna/lenne.

3) Másik tanulság: Miskolc és Debrecen rendelkezik a pályázó szervezetek székhelyének túlnyomó többségével: Miskolc 47\%-kal (17 projekt), Debrecen pedig 40\%-kal, ami 8 darabot jelent - lásd az 1. ábrát. A túlsúly várható volt, mivelhogy a két nagyváros eleve sokkal több cégnek ad otthont, de ekkora különbséget nem vártam.

1. ábra

\section{A két régióközpont túlsúlya a pályázó szervezetek székhelye tekintetében}

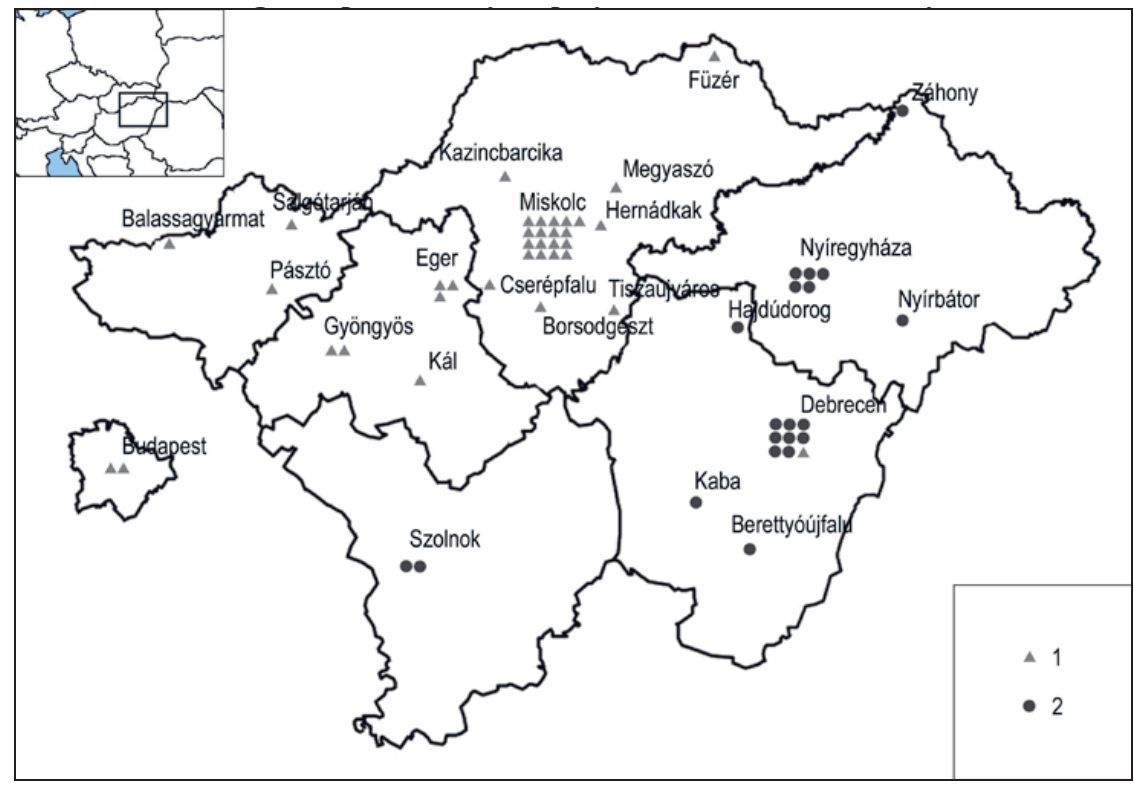

1 - észak-magyarországi pályázó, 2 - észak-alföldi pályázó

Forrás: saját szerkesztés; adatgyüjtés az Észak-magyarországi Regionális Fejlesztési Ügynökség és az Észak-alföldi Regionális Fejlesztési Ügynökség szíves engedélyével

\section{Pályázó vállalkozások típusa szerint:}

4) A típus alapján a két régió között nincs számottevő különbség. A pályázók harmada mindkét esetben mikrovállalkozás volt, másik harmaduk pedig államháztartáson kívüli nonprofit szervezet. Érdemes megjegyezni, hogy az ÉA-del ellentétben ÉM-on 3 középvállalat is pályázott.

5) Ha a cégek jogi formáját nézzük, mindkét régióban a pályázók fele kft. volt. 


\section{Klasztertagok földrajzi eloszlása}

ÉM-on a pályázó klaszterekben összesen 506 tagot számolhatunk, amiből 164 jelentkező (32\%) miskolci szervezet, 89 (18\%) pedig régión kívüli, más régióban rendelkezik székhellyel. Ugyanezen számok ÉA-ön: összesen 392 klasztertag, ebből 29\% a debreceni és $11 \%$ pedig régión kívüli.

6) Tehát a klasztertagságok alapján Észak-Alföld hajszállal kiegyensúlyozottabb képet mutat, mert itt nagyobb arányban partnerek a régióközponton kívüli vállalkozások (tehát nem debreceniek), mint Észak-Magyarországon a nem miskolciak.

7) Mindkét régió esetében találhatunk klasztertagokat más régiókból, pl. Dél-Alföld, Közép-Magyarország, de a két vizsgált régióban nagyon kevés tagot látunk egymástól. Konkrétan: ÉM-on a beadott pályázatokon csak 10 észak-alföldi cég/szervezet indult klasztertagként, ÉA-i projektekben pedig 7 ÉM-i klasztertag található. Ezek a számok rendkívül alacsonyak. Ebből vagy azt olvashatjuk ki, hogy az alakuló klaszterek partnerei - az elméletnek megfelelően - egymás földrajzi közelségében vannak; vagy pedig azt, hogy a klaszterekalakításakor a pályázó vagy pályázatíró gondolkodásmódját, terveit a régiók adminisztratív határai igen komolyan befolyásolták. ${ }^{8}$

\section{Iparági dimenziók}

8) Elméletileg ÉM gazdaságának legfontosabb ágazata a vegyipar, kohászat, gépgyártás9. Viszont elmondhatjuk, hogy ezen ágazatok súlyukhoz képest nincsenek „megfelelően” képviseltetve a cégek önálló kezdeményezéseként megpályázott klaszterekben. Ugyanez érvényes az Észak-Alföldre is: a textilipari, vegyipari, gépgyártási potenciálja ${ }^{10}$ nem tükröződik a klaszterekben, kivéve az élelmiszeripart, ami talán a régió egyik legfontosabb ágazata, és be is adtak 2 klaszterprojektet ezen a területen (1. táblázat).

\section{A két régió beérkezett projektjeinek iparági besorolása}

1. táblázat

\begin{tabular}{lcc}
\hline NACE-osztályozási rendszer & $\begin{array}{c}\text { Észak- } \\
\text { Magyar- } \\
\text { ország }\end{array}$ & $\begin{array}{c}\text { Észak- } \\
\text { Alföld }\end{array}$ \\
\hline Mezőgazdaság, erdőgazdálkodás, halászat & 7 & 2 \\
Feldolgozóipar & 1 & 2 \\
$\quad$ Élelmiszergyártás & 2 & 1 \\
Gép, gépi berendezés gyártása & 1 &
\end{tabular}

${ }^{8}$ A kiírás szerint a tagok 50\%-a kellett, hogy a régióból származzon, és a megvalósítás helyének a régióban kellett lennie. Mégis: a projektek tervezésekor - véleményem szerint biztos, ami biztos alapon - szinte kizárólag a régió és megyehatárokon belülröl mertek a pályázók tagokat a klaszterbe bevonni.

9 Észak-Magyarországi Operatív Program 2007-2013.

10 Az Észak-Alföldi Régió Stratégiai Programja 2007-2013. 
Gumi-, müanyag termék gyártása

Közúti jármü gyártása

Egyéb feldolgozóipar

Villamosenergia-, gáz-, gőzellátás, légkondicionálás

Vízellátás; szennyvíz gyűjtése, kezelése, hulladékgazd.

Építőipar

Nagykereskedelem és kiskereskedelem; gépjárművek és m.

Szállítás és raktározás

Szálláshely-szolgáltatás, vendéglátás

Információ és kommunikáció

Pénzügyi és biztosítási tevékenység

Szakmai, tudományos és műszaki tevékenység

Adminisztratív és szolgáltatást támogató tevékenység

Humán-egészségügyi, szociális ellátás

Egyéb szolgáltatás

Összesen

Forrás: saját szerkesztés, adatgyüjtés az Észak-magyarországi Regionális Fejlesztési Ügynökség és az Észak-alföldi Regionális Fejlesztési Ügynökség szíves engedélyével

\section{Összegzés}

Ha összegezni szeretnénk a két klaszterkiírásra beadott projekteket, a fenti pontokat összefoglalva elmondhatjuk, hogy Miskolc és Debrecen adta a pályázók közel felét mindkét régióban. Eger, Nyíregyháza, Salgótarján és Szolnok - mint megyeszékhelyek - várakozásomon alul teljesítettek, kevés számú pályázó származik ezen városokból (és így kevés projekt is választotta ezeket a megvalósulás helyszínéül). A pályázók mindkét régióban föként kft-ként működő mikrovállalkozások. Véleményem szerint a klasztertagok közül hiányoznak a közepes és nagyvállalatok, pénzügyi szervezetek, mint a nemzetközi irodalom szerint fontos szereplök (pl. Sölvell et al. 2003).

Sajnos a nagy, termelő iparágak sem ÉM-on, sem az ÉA-ön nincsenek megfelelően képviseltetve a klaszterekben. A projekteket benyújtó csoportok föképp a „soft” területekről származnak (mint tudományos tevékenység, turizmus vagy tanácsadás). A pályázat kiírója tervezte valamilyen módon befolyásolni az iparági eloszlást, például a következő kiírásban, ami 2010 júniusában indult, miszerint egyes iparágakban újabb klasztereket már nem fognak támogatni (pl. turizmus ÉM-on) ${ }^{12}$.

Említenek viszont más, kifejezetten preferált ágazatokat, főleg az alapján, hogy az előző, 2008-as kiíráson milyen területeken indultak klaszterek. Ez alapján előnyt élveznek ÉM-on a következő ágazatok: mechatronika; nanotechnológia; környezetipar; vegyipar;

\footnotetext{
${ }^{11}$ Észak-Alföldön 20 beérkezett projektet számolhatunk, de 4 esetében az Észak-alföldi Regionális Fejlesztési Ügynökség megtagadta az információadást, így iparáguk nem határozható meg.

12 A 2010-es kiirástervezetek alapján.
} 
megújuló energiaforrások használata; turizmus; információs technológia; élelmiszerbiztonság; járműipar. Az Alföldön ugyanezek: bio-, gén-, nano-, agrár-, farmainnovációs és infokommunikációs technológia; atommagkutatás; feldolgozóipar; termálvíz és környezetipar; logisztika; gyógyszeripar és biotechnológia ${ }^{13}$.

\section{Felhasznált irodalom}

Andersson, T. - Schwaag-Serger S. - Sörvik J. - Wise Hansson, E. (2004): The cluster policies whitebook. International Organisation for Knowledge Economy and Enterprise Development, Malmö, 248.

Az Észak-alföldi Régió Stratégiai Programja 2007-2013.

Grosz András. (é. n.): A klaszterorientált fejlesztési politika külföldi tapasztalatai.

Grosz András. (2004): Klaszterorientált fejlesztési politika Magyarországon. In: Beszteri B. (szerk.): Magyaroszág és a 21. század kihívásai az Európai Unióban. - MTA Veszprémi Területi Bizottság, Komárom, 273-288.

Grosz András. (2006): Klaszterek és innováció. In: Versenyképesség, régiók, innováció. - Business Class, Budapest, 93-101.

Lengyel Imre (2002): A regionális gazdaság-és vállalkozásfejlesztés alapvető szempontjai. In: Buzás N. - Legyel I.: Ipari parkok fejlődési lehetőségei: regionális gazdaságfejlesztés, innovációs folyamatok és klaszterek. - JATEPress, Szeged. 124-154.

Észak-alföldi Operatív Program 2007-2013.

Észak-magyarországi Operatív Program 2007-2013.

Porter, M. E. (1998): Clusters and the new economics of competition. Harvard Business Review, Nov/Dec98, Vol. 76 Issue 6, 77.

Sölvell, Ö. - Lindqvist G. - Ketels, C. (2003): The cluster initiative greenbook. Ivory Tower, Stockholm, 92.

Szanyi Miklós (2008): A versenyképesség javitása együttmüködéssel: regionális klaszterek. Napvilág Kiadó, Budapest, 200.

Személyes interjúk a két régió regionális ügynökségének képviselőivel.

${ }^{13}$ A 2010-es kiírástervezetek alapján. 